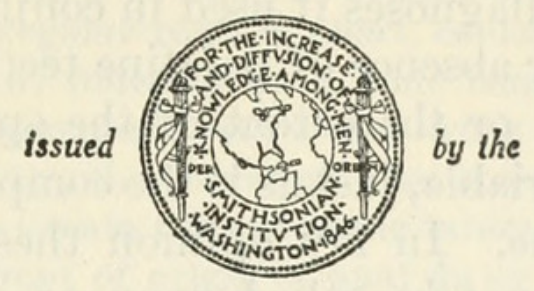

SMITHSONIAN INSTITUTION

U. S. NATIONAL MUSEUM

\title{
TWO NEW GENERA AND THREE NEW SPECIES OF CHEILODIPTERID FISHES, WITH NOTES ON THE OTHER GENERA OF THE FAMILY
}

\section{By Leonard P. Schultz ${ }^{1}$}

In studying the new forms of cheilodipterid fishes described in this paper some difficulty was experienced in deciding to which genera they should be referred. An examination of the literature and the cheilodipterid material in the National Museum suggested that the genera in this family were in great need of comparison. Therefore I have prepared a tentative key to the genera of the family Cheilodipteridae with the hope that other investigators will improve upon it as their available material is studied. As a result probably some of the genera I have placed in synonymy will be removed.

Certain ichthyologists have proposed new generic names in this group of fishes founded on characters that may not be of even specific significance, such as "a much larger, red, marine European species with considerably larger scales, longer maxillary, and differently formed head bones generally." 2 I refer here to such features as color spots, streaks, and lateral bands; number of soft rays in dorsal and anal fins; number of scale rows (especially in regard to the forms

${ }^{1}$ I wish to thank Dr. G. S. Myers, of Stanford University, for information concerning the type of Galeagra pammelas; Dr. F. P. Koumans, Rijksmuseum van Natuurlijke Historie, Leiden, for a description of the teeth of the type of Pseudamia polystigma; Dr. K. H. Barnard, South African Museum, for information on Parahynnodus and a sketch of the teeth of Neoscombrops annectens; Dr. P. Chabanaud, Muséum National d'Histoire Naturelle, Paris, for sketches of the teeth of the types of Cheilodipterus lineatus and C. quinquelineatus; Dr. S. L. Hora, Indian Museum, Calcutta, for much needed data on the type of Brephostoma carpenteri. Through exchanges with J. R. Norman, of the British Museum, I. have been able to examine paratypes of Gymnapogon japonicus and Synagrops microlepis.

${ }^{2}$ Whitley, Gilbert P., Occ. Pap. Mus. Zool. Univ. Michigan No. 405, pp. 1-4, pl. 1, 1939. 
referred to Apogon); length of fin rays or presence of filamentous rays; emargination of caudal fin. Probably some of these characters are useful for generic diagnoses if used in conjunction with other features. The presence or absence of palatine teeth and the union of the first and second dorsal or the extent of the space between these fins appear to be highly variable, just as is the completeness or incompleteness of the lateral line. In my opinion these variable characters, among others, should not be relied upon as of generic significance until their constancy has been determined for each species in any natural group.

\section{KEY TO THE GENERA OF CHEILODIPTERIDAE}

1a. Vent closer to base of pelvics than origin of anal fin.

2a. Anal rays III, 7 or 8 ; spines in first dorsal VII to IX; a pair of enlarged symphyseal canines inside front edge or margin of premaxillaries ; small canines along front margin of premaxillaries, followed by a wide band of villiform teeth posteriorly; sides of lower jaw with canines and with 1 or 2 pairs of enlarged canines near symphysis (fig. 19, a).

Acropoma Temminck and Schlegel, 1842

2b. Anal rays II, 8 ; dorsal rays VI, I, 8 or 9 ; no symphyseal canines in either jaw; small canines widely spaced on sides of upper and lower jaws; posterior half of upper jaw with a band of villiform teeth (fig. 19, $f$ ) ; no palatine teeth; vomer with teeth; peritoneum silvery ; maxillary extending past rear margin of pupil_____. Desmoamia Fowler and Bean, 1930

1b. Vent closer to origin of anal fin than base of pelvics.

$3 a$. Anal spines II.

4a. No canines in jaws even at symphysis; if teeth are present they are villiform and in narrow to wide bands (fig. 19, $h, i$ ).

5a. A thick silvery gland with black upper surface on each side of base of tongue from which a broad silvery canal extends backward on each side of isthmus to breast, then expands over base of pectoral and covers lower portion of abdomen, thence runs backward above base of anal fin to near base of candal fin rays; first dorsal VI or VII; anal II, scales cycloid; lateral line complete or incomplete_-_________-_ Siphamia Weber, 1309

$5 b$. No silvery gland as above.

6 a. Anal rays II, 9; teeth if present villiform in one or two irregular rows on jaws (fig. $19, h$ ) ; operculum with 2 flat spines; preoperculum without double edge, the lower posterior angle much produced and rounded; scale rows crossing lateral line about 36 to 60 ; anus in front of origin of anal fin a distance equal to or greater than diameter of pupil.

Epigonus Rafinesque, 1810

6b. Anal rays II, 7 to 13 ; teeth villiform in wide band on premaxillary and a narrow to wide band on dentary (fig. 19, i) ; operculum with 2 flat spines; preoperculum with double edge, posterior one not produced but with contour similar to that of anterior edge; scale rows crossing lateral line fewer than 50 ; caudal fin emarginate or rounded; lateral line complete or incomplete; anus just in front of origin of anal fin or as far distant as diameter of pupil

A.pogon Lacépède, 1802 
6c. Anal rays II, 13 to 17 ; teeth in lower jaw short, conical, hooked inward, and arranged in 1 irregular row posteriorly on dentary and in 2 such rows anteriorly, outer row smaller than inner; 1 or 2 irregular rows of short, conical teeth in anterior part of upper jaw, followed by a wide band of villiform teeth posteriorly; operculum with 2 very weak spines; preoperculum with double edge, the posterior edge strongly serrated at angle and ventrally; scale rows crossing lateral line about 23 to 28 ; anus just in front of origin of anal fin or as far distant as diameter of pupil

Archamia Gill, 1863

6 d. Anal rays II, 8 or 9 ; teeth small, equal, and pointed, uniserial in jaws; operculum with 3 or 4 short spines dorsally at rear edge near flap; preoperculum with double edge, lower angle produced; spines in first dorsal VII or VIII ; vent closer to origin of anal than base of pelvies

Oxyodon Brauer, 1906

4b. Canines present in jaws.

7a. Anal rays II, 25 ; dorsal V or VI, I, 15 to 19 ; scales about 70 ; a single series of canine teeth in lower jaw, some of which are enlarged posteriorly ; 2 pairs of enlarged canines at symphysis just inside marginal row of teeth at front of upper jaw ; sides of upper jaw with very small canines along margin, inside of which is a narrow band of villiform teeth (fig. 19, d) ; preoperculum without double edge; maxillary not reaching to under front of eye_-_-_-_-_- Dinolestes Klunzinger, 1872

7b. Anal soft rays fewer than 20 ; teeth not as above; maxillary reaching to at least under front of eye.

Sa. Lateral line complete and not interrupted.

$9 a$. Spines in first dorsal VI; scales fewer than 35 ; vent closer to origin of anal than base of pelvies; preoperculum with double edge, posterior margin near lower angle not produced.

10a. Tip of lower jaw with a few enlarged canines.

11a. No band of villiform teeth in lower jaw; lower jaw with a single series of large conical teeth, a few of which are enlarged canines widely spaced on sides of jaw and between which are small conical teeth in an irregular row; a pair or two of enlarged canines occur at symphysis of lower jaw; canine teeth in upper jaw in a group each side of a small toothless space at symphysis, no villiform teeth at tip of upper jaw, but following the canines occurs a wide band posteriorly (fig. 20, $a$ ).

Cheilodipterus Lacépède, 1802

11b. Villiform teeth in lower jaw in a band along sides but none at symphysis; lower jaw with 3 or 4 enlarged canines along midsides between which are villiform teeth; tip of lower jaw with about 3 pairs of enlarged canines; canine teeth in upper jaw located each side of symphysis in 2 or 3 pairs, anterior to which is a pair of patches of villiform teeth with a toothless space between; sides of upper jaw with a band of villiform teeth (fig. $20, b$ ).

Cheilodipterops, new genus 
10b. No canines at tip of lower jaw, but 3 to 6 pairs of enlarged canines located along midsides, tip of lower jaw with villiform teeth, this band extending along dentary; tip of upper jaw with a pair of patches of villiform teeth at symphysis, between which is a small toothless space; at sides of tip of upper jaw are 2 or 3 pairs of enlarged canines followed posteriorly by a band of villiform teeth (fig. 20,c).

Jadamga, new genus

9b. Spines in first dorsal IX, seldom VIII.

12a. Symphyseal canines at front margin of upper and lower jaws, behind canines at tips of upper jaw occurs a wide band of villiform teeth; lower jaw with a marginal series of enlarged canines inside of which is a narrow band of villiform teeth; each side of tip of lower jaw is a concave area with villiform teeth only (fig. 19, $e$ ) ; scales about 25 to 40 ; anal II, 7 ; caudal emarginate; preopercle with double edge, the lower angle not produced; maxiliary reaching to about under middle of eye_-_______ Synagrops Günther, 1887

12b. No symphyseal canines in lower jaw; 1 or 2 pairs of symphyseal canines just posterior to the marginal series at front of upper jaw (fig. 19, c) ; large conical teeth, widely spaced in a single series on both jaws; no villiform teeth present; anal II, dorsal VIII; scales about 63.

Telescopias Jordan and Snyder, 1901

8b. Lateral line incomplete or interrupted.

13a. Scales small, cycloid, anal II, 8; dorsal VI-I, 8 or 9 ; caudal rounded; symphyseal canines on upper and lower jaws; a band of villiform teeth on upper jaw, narrow laterally; in lower jaw a band of villiform teeth in front, laterally very narrow, with 2 large canines, followed by 2 smaller ones, all widely spaced, followed by a row of enlarged teeth closer together.

Pseudamia Bleeker, 1865

13b. Body scaleless; anal II, 9 or 10 ; dorsal VI-I, 10 or 11; caudal a little rounded; no symphyseal canines; a very narrow band of villiform teeth laterally on upper jaw (fig. 20,e); no teeth at symphysis of upper jaw, but at each side of this small toothless area are 4 canine teeth followed by the villiform band; symphysis of lower jaw with a small patch of villiform teeth, then on each side are a few small conical teeth; followed by about 6 enlarged and curved canines, these followed by 9 or 10 small pointed teeth, all in a single row; sides of body with short vertical series of pores in addition to the short interrupted series of lateral-line pores.

Gymnapogon Regan, 1905 
14a. Canine teeth present.

15a. Canines in upper jaw widely spaced and arranged in a single marginal series inside of which, beginning near middle of jaw, is a narrow band of villiform teeth; also enlarged canines near symphysis, just inside the marginal canine teeth (fig. 19, b) ; lower jaw with a single marginal series of canine teeth ; teeth on vomer and palatines; preopercle with double edge, not serrate; first dorsal VII to IX; anal III.

Scombrops Temminck and Schlegel, 1842

$15 b$. Only a pair of canines at symphysis of upper jaw and a similar pair of canines in lower jaw, the latter with a lateral series of closeset canines and a narrow inner band of villiform teeth more prominent posteriorly (fig. 20, d); teeth on vomer and palatines; preopercle without double edge; dorsals with IX-I, 9 or $\mathrm{X}, 11$; anal rays III, 7 or 8 ; scales about 47 , to 50 .

Neoscombrops Gilchrist, 1922

14b. No canine teeth present.

16a. Opercle, subopercle, and interopercle armed with long strong spines; the upper one on operculum bifid, the lower multifid; subopercular spine bifid at tip; both jaws armed with small conical teeth in a single row, which are a little larger and in 1 or 2 rows near the symphyses; the $V$ shaped vomer and palatines each with a single row of teeth; dorsal rays VIII-I, 8 to 10 ; anal III, 6 or 7 ; scales about 27 to 37 ; pectoral fin much longer than head Howella Ogilby, 1899

16b. Opercular spines simple; anal rays III, 7 .

17a. Opercle with 2 spines, subopercle with 2 spines, and interopercle with 1 spine; scales about 32 or 33 ; dorsal rays VIII-I, 9; teeth very small in single series on jaws; preopercle with double edge, posterior margin serrated near angle__Bathysphyraenops Parr, 1933

17b. Subopercle and interopercle without short spines, although margins of these bones may be serrated; scales about 55 to 70 ; dorsal rays $\mathrm{X}, 10$; teeth minute or villiform in a single row or a very narrow band on both jaws (fig. 19, g) ; preopercle with double edge, the posterior margin serrated.

Apogonops Ogilby, 1896 
3c. Anal rays $\mathrm{I}, 9$ or 10.

18a. No teeth on jaws, palatines, or vomer; dorsal rays $\mathrm{V}-\mathrm{I}, 10$.

Brephostoma Alcock, 1889

18b. Small teeth on jaws, palatines, and vomer, those on lower jaw and on vomer in an irregular double series; on upper jaw and on palatines teeth in a single series; dorsal rays VI-I, 11__Brinkmannella Parr, 1933

\title{
Genus ACROPOMA Tenminck and Schlegel
}

Figure $19, a$

Acropoma ${ }^{* 3}$ Temminck and Schleger, Siebold's Fauna Japonica, Pisces, pl. 12, figs. 2, 3, pp. 31-32, 1842. (Atypic; type, Acropoma japonicum Günther fixed by Günther, Catalogue of the fishes of the British Museum, vol. 1, p. 250,1859 .)

\section{Genus DESMOAMIA Fowler and Bean}

\author{
Figure $19, f$
}

Desmoamia* Fowler and Bean, U. S. Nat. Mus. Bull. 100, vol. 10, p. 123, 1930. (Genotype, Cheilodipterus zonatus* Smith and Radcliffe: U. S. N. M. No. 70253, type.)

The following species, represented by a holotype in the National Museum, is referred to the genus Desmoamia:

Cheilodipterus nigrotaeniatus* SмIтH and RAdchIFFe, in Radeliffe, Proc. U. S. Nat. Mus., vol. 41, p. 442, pl. 37, fig. 3, 1912. (U. S. N. M. No. 70252.)

\section{Genus SIPHAMIA Weber}

Siphamia Weber, Notes Leyden Mus., vol. 31, note 4, p. 168, 1909. (Orthotype, Siphamia tubifer Weber.)

Adenapogon McCulloch, Rec. Australian Mus., vol. 13, No. 4, p. 132, pl. 21, fig. 2, 1921. (Genotype, Apogon roseigaster Ramsay and Ogilby.)

Scopelapogon Whitcex, Rec. Australian Mus., vol. 19, p. 74, 1933. (Orthotype, Adenapogon (Scopelapogon) woodi MeCulloch.)

Fodifoa Whitley, Mem. Queensland Mus., vol. 11, pt. 1, p. 26, 1936. (Genotype, Foa fistulosa Weber.)

The following species, represented by a type in the National Museum, is referred to the genus Siphamia:

Amia versicolor* Smith and RAdCLIFFe, in Radcliffe, Proc. U. S. Nat. Mus., vol. 41 , p. 257 , fig. 3, 1911 . (U.S.N.M. No. 68401.)

${ }^{3}$ All genera and types of species marked with an asterisk (*) are represented by material in the U. S. National Museum and have been examined by the author. 


\section{Genus EPIGONUS Rafinesque}

Figure $19, h$

Epigonus Rafinesque, Indice d'ittiologia siciliana . .., p. 64, 1810. (Orthotype, Epigonus macrophthalmus Rafinesque.)

Pomatomus (Risso) Cuvier and Valenciennes, Histoire naturelle des poissons, vol. 2, p. 171, 1828. (Type, Pomatomus telescopium Risso.)

Telescops BıЕEkER, Arch. Néerl. Sci. Nat., vol. 11, pt. 1, p. 261, $1876 . \quad$ (Orthotype, Pomatomus telescopium Risso.)

Pomatomichthys GigLIoli, Elenco ... e catalogo . . dei pesci italiani, p. 20, 1850. (Orthotype, Pomatomichthys constanciae Giglioli=Pomatomus telescopium Risso, a synonym of Epigonus.)

Fynnodus* Gilbert, Bull. U. S. Fish Comm., vol. 23 (1903), pt. 2, p. 617, pl. 79, 1905. (Orthotype, Hynnodus atherinoides* Gilbert: U.S.N.M. No. 51601 , type. $)^{4}$

Xystramia* Jordan, Copeia, No. 44, p. 46, 1917. (Orthotype, Glossamia pandionis $($ Goode and Bean $)=$ Apogon pandionis* Goode and Bean: U.S.N.M. No. 26628, type.)

Scepierias Jordan and Jondan, Mem. Carnegie Mus., vol. 10, No. 1, p. 44, pl. 2, 1922. (Type, Scepterias fragilis Jordan and Jordan. $)^{4}$

Parahynnodus Barnard, Ann. Mag. Nat. Hist., ser. 9, vol. 20, p. 69, July 1927. (Orthotype, Parahynnodus robustus Barnard, Ann. South African Mus., vol. 21 , p. 525 , pl. 22 , fig. 4 , Oct. 1927.) ${ }^{4}$

The following species, represented by a type in the National Museum, is referred to the genus Epigonus:

Hynnodus megalops* Smith and RAdchiffe, in Radcliffe, Proc. U. S. Nat. Mus., vol. 41 , p. 445 , pl. 38 , fig. 3 , 1912 . (U.S.N.M. No. 70255.)

\section{Genus APOGON Lacépède}

Figure 19, $i$

Amia Grovow, Zoophylacii ..., p. 80, 1763 (nonbinomial). (Type, Amia moluccensis Cuvier and Valenciennes.)

Apogon LACÉPÈDE, Histoire naturelle des poissons, vol. 3, p. 411, 1802. (Type, Apogon ruber Lacépède.)

Ostorhinchus LACÉPÈDE, Histoire naturelle des poissons, vol. 4, p. 23, 1802. (Type, Ostorhinchus fleurieu Lacépède.)

Dipterodon LAć́pède, Histoire naturelle des poissons, vol. 4, p. 167, 1802. (Type, Dipterodon hexacanthus Lacépède, designated by Jordan and Evermann, Genera of fishes, vol. 1, p. 63, 1917.)

Macrolepis Rafinesque, Analyse de la nature ..., p. 89, $1815 . \quad$ (Type, Apogon ruber Lacépède; proposed to replace Apogon Lacépède.)

Apogonoides BLEEKER, Journ. Indian Archipelago, vol. 3, p. 70, 1849. (Orthotype, Apogonoides macassariensis Bleeker.)

?Microichthys RüpPELL, Verzeichniss in dem Museum Senckenbergischen ... Sammlungen: Pt. 4, Fische und deren Skelette, p. 1, 1852. (Orthotype, Microichthys coccoi Rüppell.)

- Matsubara, Journ. Imp. Fish. Inst., vol. 31, No. 2, pp. 119-130, 1936, has reviewed the genera Hynnodus, Parahynnodus, and scepterias and is of the opinion that they should be referred to Epigonus, in which opinion I concur. 
Apogonichthys BleEker, Nat. Tijdschr. Nederl.-Indië, vol. 6, pp. 312, 321, 1854. (Type, Apogonichthys perdix Bleeker.)

Amia Gronow, Catalogue of fish collected and described by Laurence Theodore Gronow, now in the British Museum (edited by Günther), p. 173, 1854. (Orthotype, Amia percaeformis Gronow.)

Monoprion Poex, Mem. Hist. Nat. Cuba, vol. 2, p. 123, 1860. (Orthotype, Monoprion maculatus Poey.)

Lepidamia GrLl, Proc. Acad. Nat. Sci. Philadelphia, 1863, p. 81. (Orthotype, Amia kalosoma Bleeker.)

Glossamia Gill, Proc. Acad. Nat. Sci. Philadelphia, 1863, p. 82. (Orthotype, Apogon aprion Richardson.)

Mionorus Krefre, Proc. Zool. Soc. London, 1867, p. $943 . \quad$ (Orthotype, Mionorus lunatus Krefft.)

Pristiapogon Klunzinger, Verh. zool.-bot. Ges. Wien, 1870, p. 715. (Type, Apogon fraenatus Valenciennes.)

?Vincentia Castelnau, Proc. Zool. Acclim. Soc. Victoria, vol. 1, p. 245, 1872. (Type, Vincentia waterhousei Castelnau.)

Gulliveria Castelnau, Proc. Linn. Soc. New South Wales, vol. 3, p. 45, 1878. (Logotype, Gulliveria fusca Castelnau=Apogon aprion, a synonym of Glossamia.)

Monosira Poex, Anal. Soc. Españ. Hist. Nat., Madrid, vol. 10, p. 326, 1881. (Type, Monosira stahli Poey.)

Fowleria Jordan and Evermann, Bull. U. S. Fish Comm., vol. 22 (1902), p. 180, 1903. (Type, Apogon auritus Valenciennes.)

Foa * Jordan and Evermann, in Jordan and Seale, Proc. U. S. Nat. Mus., vol. 28, p. 779, July 3, 1905. (Orthotype, Foa fo Jordan and Seale: U. S. N. M. No. 51735, type.)

Foa * Jordan and Evermann, Bull. U. S. Fish Comm., vol. 23 (1903), pt. 1, p. 210, fig., July 29, 1905. (Orthotype, Fowleria brachygrammus * Jenkins: U. S. N. M. No. 50699, type.)

Astrapogon Fowler, Proc. Acad. Nat. Sci. Philadelphia, 1906, p. 527. (Type, Apogonichthys stellatus Cope.)

Rhabdamia WeBer, Notes Leyden Mus., vol. 31, p. 165, 1909. (Orthotype, Rhabdamia clupeiformis Weber.)

Neamia* Smith and Radcliffe, in Radcliffe, Proc. U. S. Nat. Mus., vol. 41, p. 441, 1912. (Type, Neamia octospina* Smith and Radeliffe: U.S.N.M. No. 70251, type.)

Nectamia Jordan, Copeia, No. 44, p. 46, 1917. (Type, Apogon fuscus Quoy and Gaimard.)

Zoramia Jordan, Copeia, No. 44, p. 46, 1917. (Type, Apogon graeffi Günther.)

Brephamia Jordan, in Jordan and Jordan, Mem. Carnegie Mus., vol. 10, No. 1, p. 43, 1922. (Type, Amia parvula* Smith and Radcliffe.)

Gronovichthys Whitcey, Rec. Australian Mus., vol. 17, p. 302, footnote, 1929; Mem. Queensland Mus., vol. 10, pt. 1, p. 11, 1930. (Orthotype, Amia percaeformis Gray.)

Sphaeramia Fowler and BEAN, U. S. Nat. Mus. Bull. 100, vol. 10, p. 29, 1930. (Genotype, Apogon nematoptera Bleeker.)

Ioamia Fowler and BeAN, U. S. Nat. Mus. Bull. 100, vol. 10, p. 130, 1930. (Genotype, Apogonichthys gracilis Bleeker.)

Lovamia Whitley, Mem. Queensland Mus., vol. 10, pt. 1, p. 10, 1930. (Orthotype, Mullus fasciatus White.)

Yarica Whitlex, Mem. Queensland Mus., vol. 10, pt. 1, p. 12, 1930. (Orthotype, Apogon hyalosoma var. torresiensis Castelnau.) 
Pterapogon Koumans, Zoöl. Meded. Rijksmus. Nat. Hist. Leiden, vol. 16, p. 78, fig. 2, 1933. (Orthotype, Pterapogon kauderni Koumans.)

Kurandapogon* WhitLeY, Occ. Pap. Mus. Zool. Univ. Michigan, No. 405, pp. 1-4, pl. 1, 1939. (Genotype, Kurandapogon blanchardi* Whitley.)

The following species, represented by types in the U. S. National Museum, have been examined by the author and are referred to the genus Apogon:

A mia retrosella GILL, Proc. Acad. Nat. Sci. Philadelphia, 1862, p. 251. (U.S.N.M.

Nos. $2454,2997,4413$.)

Apogon alutus Jordan and Gilbert, Proc. U. S. Nat. Mus., vol. 5, p. 279, 1882. (U.S.N.M. No. 30874.)

Apogon atricaudus JoRDAN and MCGREgor, in Jordan and Evermann, U. S. Nat. Mus. Bull. 47, p. 2853, 1898. (U.S.N.M. No. 48527.)

Apogon sellicauda Evermann and Marsh, Bull. U. S. Fish Comm., vol. 20, pt. 1, p. 143, fig. 40, 1900. (U.S.N.M. No. 49529.)

A pogon unicolor Döderlein, in Jordan and Snyder, Proc. U. S. Nat. Mus., vol. 23, p. 749, pl. 33, 1901 . (U.S.N.M. No. 49708.)

Apogonichthys waikiki Jordan and Evermann, Bull. U. S. Fish Comm., vol. 22, p. 179,1903 . (U.S.N.M. No. 50639.)

Apogon snyderi Jordan and Evermann, Bull. U. S. Fish Comm., vol. 22, p. 180, 1903. (U.S.N.M. No. 50640.)

Apogon menesemus Jenkins, Bull. U. S. Fish Comm., vol. 22, p. 448, 1903. (U.S.N.M. No. 50700.)

Apogon erythrinus Snyper, Bull. U. S. Fish Comm., vol. 22, p. 526, pl. 9, fig. 17, 1904. (U.S.N.M. No. 50876.)

A pogon evermanni Jordan and SNyder, Proc. U. S. Nat. Mus., vol. 28, p. 123, 1904. (U.S.N.M. No. 51487.)

Amia gilberti JoRdan and Seale, Proc. U. S. Nat. Mus., vol. 28, p. 777, fig. 3, 1905. (U.S.N.M. No. 51941.)

Mionorus mydrus Jordan and Seale, Proc. U. S. Nat. Mus., vol. 28, p. 778, fig. 4, 1905. (U.S.N.M. No. 51946.)

Amia exostigma JoRdan and Stakks, in Jordan and Seale, Bull. U. S. Bur. Fish., rol. 25 , p. 238 , fig. 31,1906 . (U.S.N.M. No. 51732.)

Amia doryssa, Jordan and Seale, Bull. U. S. Bur. Fish., vol. 25, p. 245, fig. 39, 1906. (U.S.N.M. No. 51812.)

Foa vaizlae Jondan and Seale, Bull. U. S. Bur. Fish., vol. 25, p. 249, fig. 43, 1906. (U.S.N.M. No. 51734.)

Apogonichthys isostigma JoRdan and SEALE, Bull. U. S. Bur. Fish., vol. 25, p. 251, fig. $45,1906 . \quad$ (U.S.N.M. No. 51736.)

Amia jenkinsi Evermann and Seale, Bull. U. S. Bur. Fish., vol. 26, p. 73, fig. 9, 1907. (U.S.N.M. No. 55907.)

Apogonichthys mentalis Evermann and Seale, Bull. U. S. Bur. Fish., vol. 26, p. 74 , fig. 10, 1907. (U.S.N.M. No. 55905.)

Apogonichthys nofae SNYDER, Proc. U. S. Nat. Mus., vol. 36, p. 599, 1909 . (U.S.N.M. No. 62947.)

A mia compressa Smith and Radcliffe, in Radeliffe, Proc. U. S. Nat. Mus., vol. 41, p. 246 , pls. 20, 21, 1911. (U.S.N.M. No. 68398.)

Amia angustata SмiтH and RadclifFe, in Radcliffe, Proc. U. S. Nat. Mus., vol. 41, p. 253 , fig. 1,1911 . (U.S.N.M. No. 68399 .)

Amia robusta SмITH and RADCLIFFe, in Radcliffe, Proc. U. S. Nat. Mus., vol. 41, p. 254 , fig. 2 , 1911 . (U.S.N.M. No. 68400 .)

Amia diencaea Sмrth and RadchIffe, in Radcliffe, Proc. U. S. Nat. Mus., vol. 41, p. 431, pl. 34, fig. 1, 1912 . (U.S.N.M. No. 70243.) 
Amia parvula Smith and RAdclifTe, in Radeliffe, Proc. U. S. Nat. Mus., rol. 41, p. 432 , pl. 34 , fig. 2 , 1912 . (U.S.N.M. No. 70244 .)

Amia hyalina Sмith and RAdchiffe, in Radcliffe, Proc. U. S. Nat. Mus., vol. 41, p. 433 , pl. 36, fig. 2 , 1912 . (U.S.N.M. No. 70245.)

Amia diversa Smith and Radcliffe, in Radcliffe, Proc. U. S. Nat. Mus., vol. 41, p. 434 , pl. 37 , fig. 1 , 1912 . (U.S.N.M. No. 70246.)

Amia nigrocincta Sмit p. 435 , pl. 37 , fig. 2 , 1912 . (U.S.N.M. No. 70247.)

Amia uninotata Smith and Radcliffe, in Radcliffe, Proc. U. S. Nat. Mus., vol. 41, p. 436, pl. 34, fig. 3, 1912 . (U.S.N.M. No. 70248.)

Amia striata Sмith and RadchIfFe, in Radeliffe, Proc. U. S. Nat. Mus., vol. 41, p. 437 , pl. 35, fig. 1, 1912 . (U.S.N.M. No. 68403.)

Amia albomarginata Sмith and Radcliffe, in Radcliffe, Proc. U. S. Nat. Mus., vol. 41 , p. 438 , pl. 35 , fig. 2 , 1912 . (U.S.N.M. No. 68402.)

Amia atrogaster Smith and RadclifFe, in Radcliffe, Proc. U. S. Nat. Mus., vol. 41, p. 439 , pl. 35, fig. 3, 1912 . (U.S.N.M. No. 70249.)

Amia guadalupensis Osburn and Nichors, Bull. Amer. Mus. Nat. Hist., vol. 35, art. 16 , p. 160 , fig. 9,1916 . (U.S.N.M. No. 87545. )

Kurandapogon blanchardi WhiтLеY, Occ. Pap. Mus. Zoöl. Univ. Michigan, No. 405, pp. 1-4, pl. 1, 1939 . (U.S.N.M. No. 109466.)

\section{Genus ARCHAMIA Gill}

Archamia Gru, Proc. Acad. Nat. Sci. Philadelphia, 1863, p. 81. (Orthotype, Apogon bleekeri Günther.)

The characters given in the key for this genus were based mostly on specimens of Archamia lineolata (Cuvier and Valenciennes), U.S.N.M. Nos. 52203 and 89255, from Apia.

\section{Genus OXYODON Brauer}

Oxyodon Braukr, Wissenschaftliche Ergebnisse der Deutschen Tiefsee-Expedition auf dem Dampfer Valdivia 1898-99, vol. 15, p. 287, fig. 172, 1906. (Orthotype, Oxyodon macrops Brauer.)

\section{Genus DINOLESTES Klunzinger}

Figure 19, $d$

Dinolestes* Klunzinger, Areh. Naturg., vol. 38, pt. 1, p. 29, 1872. (Type, Dinolestes muelleri Klunzinger.)

Lanioperca GüNther, Ann. Mag. Nat. Hist., ser. 4, vol. 10, p. 183, 1872. (Orthotype, Lanioperca mordax Günther=Dinolestes muelleri Klunzinger.)

Neosphyraena Castelnau, Proc. Zool. Acclim. Soc. Victoria, vol. 1, p. 96, 1872. (Orthotype, Neosphyraena multiradiata Castelnau.)

\section{Genus CHEILODIPTERUS Lacépède}

Figure 20, $a$

C'heilodipterus* LAĆ́Pède, Histoire naturelle des poissons, vol. 3, p. 539, 1802. (Type, Cheilodipterus lineatus Lacépède, as restricted by Cuvier and Valenciennes.)

Aspro (Commerson) LACÉPÈDE, Histoire naturelle des poissons, vol. 4, p. 273, 1803. (Type, Cheilodipterus macrodon Lacépède, as restricted by Jordan.) 
Clodipterus Rafinesque, Analyse de la nature ..., pp. 86, 88, 1815. (Substitute for Cheilodipterus Lacépède.)

Chilodipterus GüNTHER, Catalogue of the fishes of the British Museum, vol. 1, p. 248, 1859. (Type, Cheilodipterus lineatus Lacépède.)

Paramia Bleeker, Nederl. Tijdschr. Dierk., vol. 1, p. 233, 1863. (Type, Cheilodipterus lineatus Lacépède; proposed to replace Cheilodipterus

Lacépède.) Acanthapogon* Fowler, Acad. Nat. Sci. Philadelphia Monogr. 2, p. 197, pl. 8,
fig. 18, 1938. (Genus based on tiny young; type, Acanthapogon vanderbilti* Fowler: U.S.N.M. No. 107189, paratypes.)

The following species, represented by a holotype in the National Museum, is referred to the genus Cheilodipterus:

Chilodipterus affinis* PoEY, Ann. Lyc. Nat. Hist. New York, vol. 11, p. 58, 1876. (U.S.N.M. No. 37416.)

\section{CHEILODIPTEROPS, new genus}

Figure $20, b$

Two or three pairs of canines at symphysis of lower jaw, each side of lower jaw with three or four enlarged canines; posterior to the symphyseal canines occur villiform teeth; each side of tip of upper jaw with a small patch of villiform teeth, followed by three pairs of canines, remainder of jaw with wide band of villiform teeth; vomer and palatines with small teeth, other characters are those of the new species.

Genotype-Cheilodipterops isostigma, new species.

\section{CHEILODIPTEROPS ISOSTIGMA,* new species}

Holotype-U.S.N.M. No. 30657. A specimen $74 \mathrm{~mm}$. in standard length taken at New Guinea by the Linnean Society, Sydney, Australia, previous to 1882 .

Description.-Body compressed, elongate, with large ctenoid scales; lateral line continuous but not extending on caudal fin rays; interorbital space slightly concave; maxillaries slipping under preorbital anteriorly, and a little posteriorly a small supplementary bone posteriorly on upper edge of maxillary; maxillary reaching to beyond a vertical line from rear edge of pupil; premaxillary protractile, its upper edge concealed by preorbital bones; mouth terminal, jaws equal, the lower fitting inside the canines of upper jaw; small symphyseal knob at tip of lower jaw; pelvic rays I, 5; dorsal VI-I, 9 ; anal II, 8 , the first spine very small, about $1 / 3$ pupil; pectoral rays $11-11$; principal caudal rays 17 , scales $21 / 2+25+51 / 2$; cheeks with large scales; gill rakers on first arch $5+15$ and $5+16$; preoperculum with double edge, the posterior edge finely serrated; pseudobranchiae present; operculum with one very weak flat spine that does not extend beyond the membranous bone; anus about the diameter of eye in 
advance of origin of anal fin, much closer to origin of anal than insertion of pelvics, gill membranes extending far forward not joined to isthmus; branchiostegals 6 ; caudal fin slightly emarginate.

Measurements.-The measurements outside the parentheses are in millimeters, and those in the parentheses are expressed in hundredths of the standard length. Distance from tip of snout to base of midcaudal fin rays 74; greatest depth of body 19 (25.7); least depth of caudal peduncle $10(13.5)$; length from base of last anal ray to base of midcaudal fin rays 21 (28.4); head 29 (39.2) diameter of eye 9 (12.2) snout $6.9(9.3)$; bony interorbital space $3.7(5.0)$; length of longest pectoral fin ray 14.7 (19.9); length of second (longest) anal spine 10.4 (14.1); length of longest dorsal spine or second spine 13 (17.5) ; tip of snout to origin of spiny dorsal fin 32.5 (44.0); tip of snout to origin of anal fin $50(67.7)$; tip of snout to insertion of pectoral fin 29 (39.2); tip of snout to insertion of pelvic fins 29.6 (40.0) ; tip of snout to center of anus 42.7 (57.7) ; length of maxillaries $10.5(14.2)$.

Color in alcohol.-Peritoneum silvery; sides of body with five narrow, longitudinal, brown streaks and a midventral one on breast between pelvics; on occiput begins the most dorsal streak, continuing along midline of back, dividing just in front of origin of dorsal, a branch passing along each side of base of rays, uniting just behind base of dorsal, and continuing along middorsal line of caudal peduncle; second one begins at tip of snout passing along top of head at dorsal edge of orbit, over posttemporal, and along lateral line, leaving it a little in front of origin of dorsal and continuing along upper side of caudal peduncle; the median streak begins on tip of snout, passes through eye and along midside of body, ending on caudal peduncle; the next one begins on tip of lower jaw and passes just below eye and along midventral side to caudal fin base; the ventral streak begins on tip of lower jaw, extending along ventral margin of

FIGURE 19.- Upper and lower jaws of cheilodipterid fishes, showing arrangement of the teeth; bands and patches of villiform teeth are blackened; white spots in black area represent canine teeth, usually in a single row along outer margin; vomerine and palatine teeth not shown: a, Acropoma japonicum, diagram based mostly on U.S.N.M. Nos. 49823, 49824, and 57756 ; $b$, Scombrops, based on U.S.N.M. Nos. 48138, 49932, 57524, and 59619 (specimens of $S$. cheilodipterus and S. boops); c, Telescopias gilberti, based on U.S.N.M. No. 57540, a paratype; $d$, Dinolestes muelleri, based on U.S.N.M. Nos. 49712 and 49713; e, Synagrops, based on U.S.N.M. Nos. 51434 (S. japonica), 39338 (type), 39346, 44621, 74325-74328 (all paratypes of $S$. bella), 70254 (type of $S$. serratospinosa), 70250 (type of Amia grossidens), and 47732 (type of Melaniostoma argyreum); $f$, Desmoamia zonatus, based on U.S.N.M. No. 70253 (type) and 70252 (type of Cheilodipterus nigrotaeniatus); g, Apogonops, based on U.S.N.M. No. 74085 (type of Parasphyraenops atrimanus); h, Epigonus, based on U.S.N.M. Nos. 44827 and 49351 (specimens of E. telescopius); $i$, Apogon, based on numerous specimens of several species. 

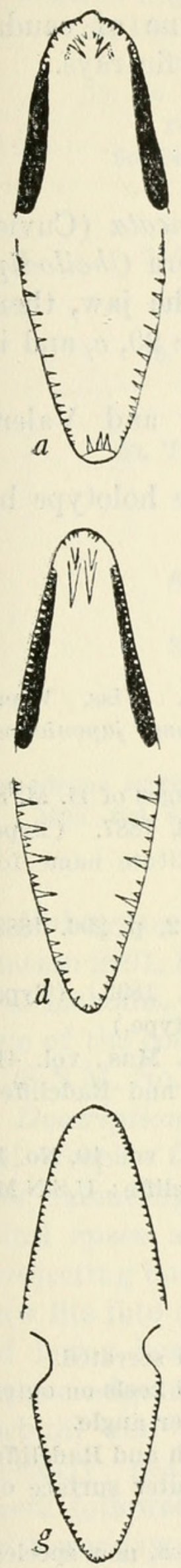
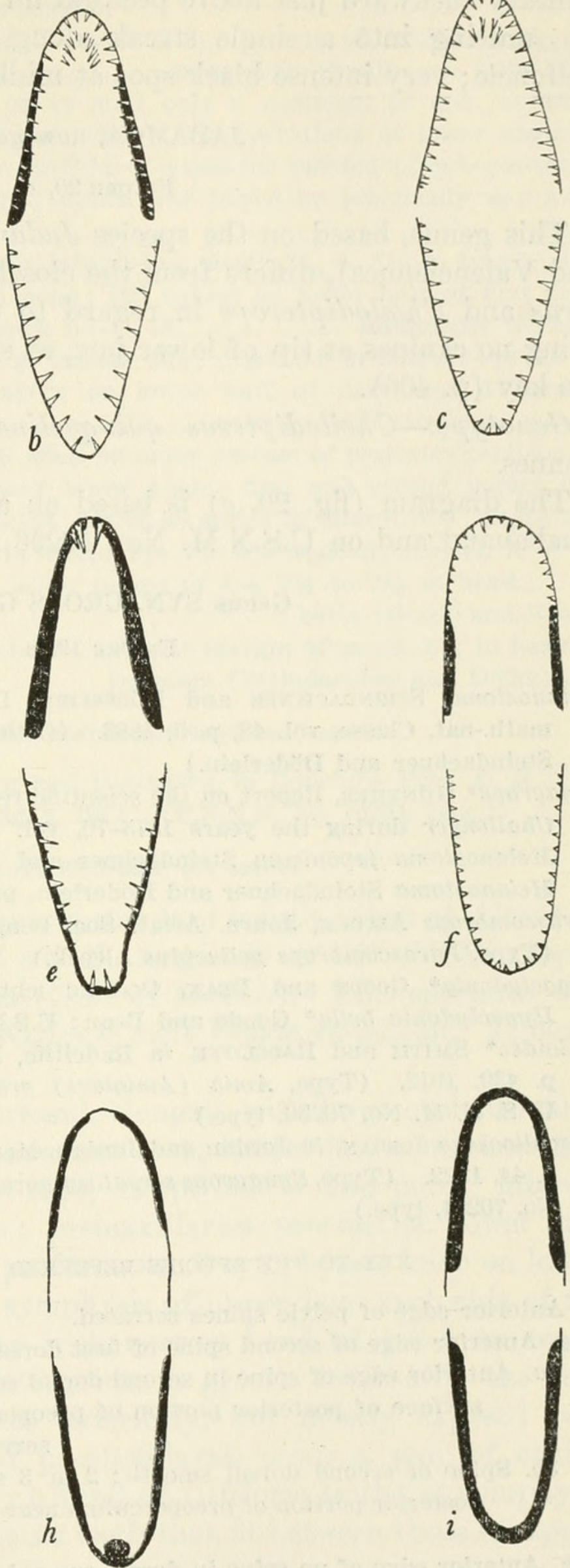

Figure 19.- See opposite page for explanation 
dentary backward just above pectoral fin base and along base of anal fin, uniting into a single streak along midventral line of caudal peduncle; very intense black spot at midbase of caudal fin rays.

\section{JADAMGA, new genus}

Figure 20, $c$

This genus, based on the species Jadamga quinquelineata (Cuvier and Valenciennes), differs from the closely related genera Cheilodipterus and Cheilodipterops in regard to the teeth in the jaw, there being no canines at tip of lower jaw, as shown in figure $20, c$, and in the key (p. 406).

Genotype.-Cheilodipterus quinquelineatus* Cuvier and Valenciennes.

The diagram (fig. 20, c) is based on a sketch of the holotype by Chabanaud and on U.S.N.M. Nos. 52296 and 65976.

\section{Genus SYNAGROPS Günther}

Figure 19,e

Melanostoma SteindachNer and Döperlein, Denkschr. Akad. Wiss. Wien. math.-nat. Classe, vol. 48, p. 5, 1883 . (Orthotype, Melanostoma japonicum* Steindachner and Döderlein.)

Synagrops* GüNTHER, Report on the scientific results of the voyages of H. M. S. Challenger during the years 1873-76, vol. 22, pt. 57, p. 16, 1887. (Type, Melanostoma japonicum Steindachner and Döderlein; substitute name for Melanostoma Steindachner and Döderlein, preoccupied.)

Parascombrops Alcock, Journ. Asiat. Soc. Bengal, vol. 58, pt. 2, p. 296, 1889. (Type, Parascombrops pellucidus Alcock.)

Hypoclydonia* Goone and BEAN, Oceanic ichthyology, p. 236, 1895. (Type, Hypoclydonia bella* Goode and Bean: U.S.N.M. No. 39338, type.)

Amioides* Sмith and RAdchifte, in Radcliffe, Proc. U. S. Nat. Mus., vol. 41, p. 439, 1912. (Type, Amia (Amioides) grossidens* Smith and Radeliffe: U. S. N. M. No. 70250, type.)

Maccullochina Jordan, in Jordan and Jordan, Mem. Carnegie Mus., vol. 10, No. 1. p. 44, 1922. (Type, Synagrops serratospinosa* Smith and Radcliffe: U.S.N.M. No. 70254 , type.)

\section{KEY TO THE SPECIES REFERRED TO SYNAGROPS}

1a. Anterior edge of pelvic spines serrated.

$2 a$. Anterior edge of second spine of first dorsal and of anal fin serrated.

$3 a$. Anterior edge of spine in second dorsal serrated; no small keels on outer surface of posterior portion of preoperculum near lower angle.

serratospinosa Smith and Radcliffe

3b. Spine of second dorsal smooth; 2 or 3 small keels on outer surface of posterior portion of preoperculum near lower angle.

spinosa, new species

$2 b$. Anterior edge of no spine in dorsal or anal fins serrated.

$4 a$. No keels on outer surface of posterior portion of preoperculum near lower angle philippinensis (Günther)

4b. Three keels on outer surface of posterior portion of preoperculum near lower angle argyrea (Gilbert and Cramer) 
1b. Anterior edge of pelvic spines smooth.

$5 a$. One obviously strong humeral spine; margin of anterior ridge of preopercle smooth

$5 b$. No humeral spines or at most only a rudiment of one; anterior ridge of preoperculum with a few serrations at lower angle.

$6 a$. No keels on outer surface of posterior portion of preoperculum near lower angle; dorsal fins joined or practically so; Anal II, 9 .

$7 a .^{5}$ About 40 scales in lateral line, depth $3 \frac{1}{3}$ to $3 \frac{1}{2}$ in length; eye $3 \frac{1}{3}$ to $3 \frac{3}{4}$ in head; gill rakers on lower half of first arch 13 or 14 , formula $5+1+14$

7b. About 35 scales in lateral line; depth 3.3 in length; eye 2.9 in head; gill rakers on lower half of first arch 17 (total

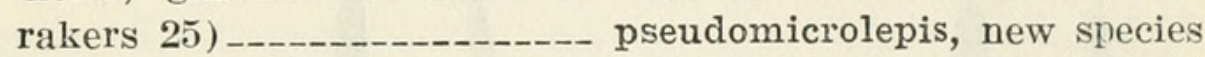

6b. Two or three small keels on outer surface of posterior portions of preoperculum near lower angle; first and second dorsal fins definitely separated; about 30 scales in lateral line; depth $3 \% / 4$ to more than 4 in length, eye 3 to $3 \frac{1}{2}$ in head; anal II, 7.

$8 a .^{5}$ Maxillary to below center of eye, $2 \frac{1 / 4}{4}$ to $2 \frac{1}{3}$ in head.

bella (Goode and Bean)

$8 b .^{5}$ Maxillary to below anterior margin of pupil, $2 \frac{1}{2}$ in head. japonica (Steindachner and Döderlein)

SYNAGROPS SERRATOSPINOSA Smith and Radcliffe

Synagrops serratospinosa* SMTtH and RAdCLIFfe, in Radcliffe, Proc. U. S. Nat. Mus., vol. 41, p. 444, pl. 38, fig. 2, 1912 . (U.S.N.M. No. 70254, type.)

SYNAGROPS SPINOSA, new species

Holotype.-A male, $105 \mathrm{~mm}$. in standard length, taken at Albatross station 2401 , latitude $28^{\circ} 38^{\prime} 30^{\prime \prime} \mathrm{N}$., longitude $85^{\circ} 52^{\prime} 30^{\prime \prime} \mathrm{W}$., depth 142 fathoms, March 14, 1885 (Gulf of Míxico). This specimen was one of the cotypes of Hypoclydonia bella Goode and Bean. It bears U.S.N.M. No. 74324 .

Description.-Body compressed, elongate with large cycloid scales, all except a few of which have been lost; lateral line continuous but not extending on caudal fin rays, except one or two pores; interorbital space slightly convex; premaxillaries protractile, lower jaw projecting but not entering profile, a small symphyseal knob on lower jaw fits into a concavity at symphysis of upper jaw; each side of tip of lower jaw is a concavity with narrow band of villiform teeth, upper edge of maxillary fitting into a groove formed by the suborbital and preorbital bones anteriorly, but mostly exposed posteriorly; near symphysis of premaxillaries occur a pair of canine teeth followed posteriorly by a band of villiform teeth; at symphysis of lower jaw is a pair of canine teeth that fit between those of upper

5 These portions of the key were taken from Norman, Discovery Reports, vol 12, p. 11, 1935. Our limited material does not indicate these differences when specimens of the same size are compared, and I am unable to find any character that will separate our Japanese and Atlantic material of bella and japonica with certainty. 
jaws; posterior to the concavity near tip of lower jaw occur 5 and 8 canine teeth along midside of jaw behind which is a band of villiform teeth; small teeth on vomer and palatines; pelvics I, 5 ; the spine serrated on anterior edge; dorsal rays IX, I, 9, the anterior edge of second dorsal spine serrated beyond tip of first spine, no other spine in dorsal fins serrated; the space between dorsals equal to width of pupil; the third dorsal spine longest; anal rays II, 7, the anterior edge of the second spine serrated, beyond the tip of the first; pectoral rays.
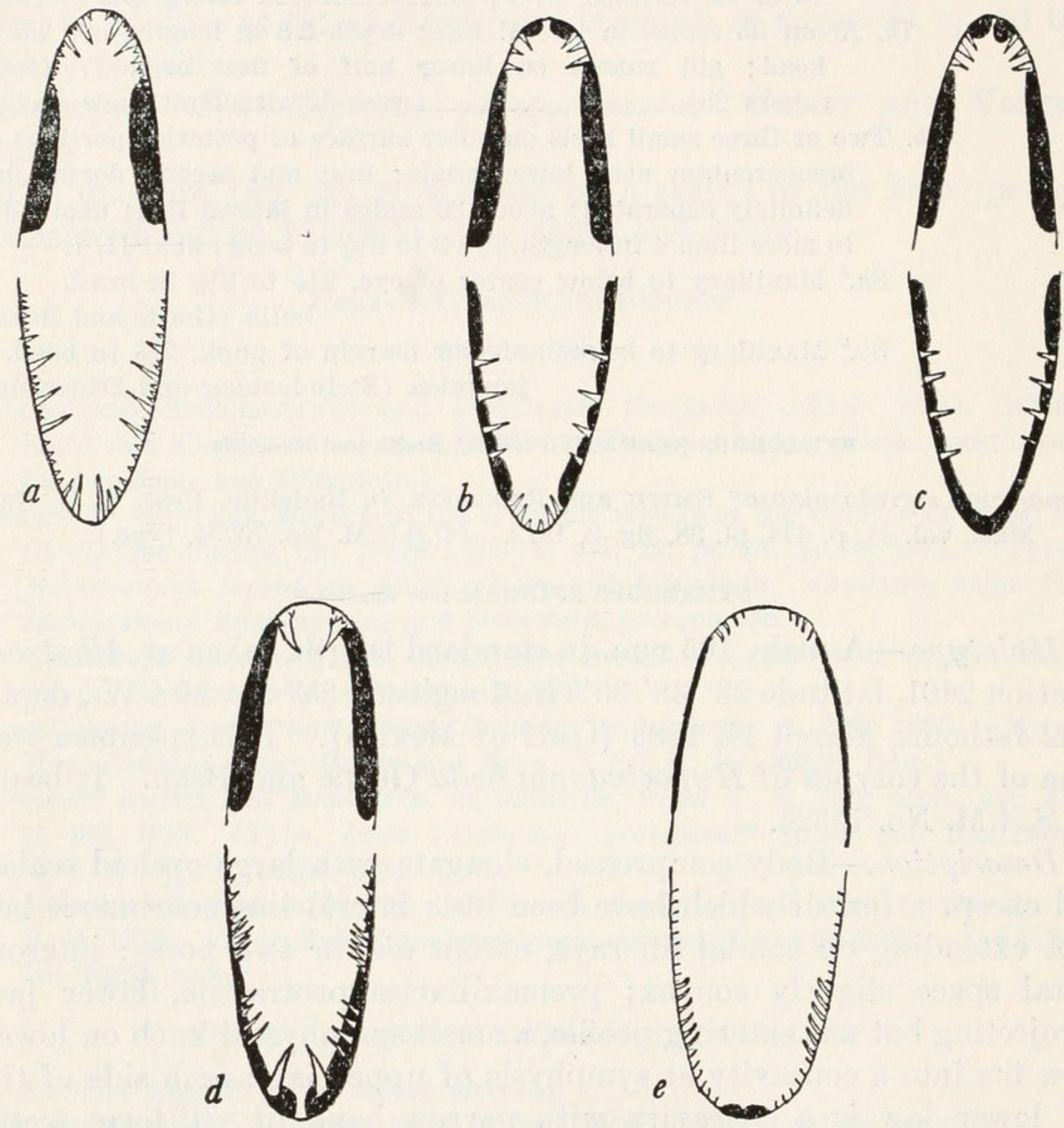

FigURE 20.- Upper and lower jaws of cheilodipterid fishes, showing arrangement of the teeth; bands and patches of villiform teeth are blackened; white spots on black area represent canine teeth, usually in a single row along outer margin; vomerine and palatine teeth not shown: a, Cheilodipterus, diagram based on U.S.N.M. Nos. 30658 and 49287 (C. lineatus), 52410 and 65604 (C. macrodon), 30541 (probably C. octovittatus), and 37416 (type of $C$. affinis); b, Cheilodipierops, based on U.S.N.M. No. 30657 (holotype of $C$. isostigma); c, Jadamga, based on U.S.N.M. Nos. 52296 (7 specimens), 65976 (1 specimen), and the holotype from a sketch of $J$. quinquelineata by Chabanaud; $d, N e o s c o m b r o p s$, based on a sketch by Barnard from a specimen of $N$. annectens in the South African Museum; e, Gymnapogon, based on U.S.N.M. No. 108821 (paratype of G. japonicus). 
16 on each side; gill rakers on first arch $5+14$; about 31 scale rows crossing lateral line; preoperculum with double edge, the lower angle of the anterior edge with fine serrations, the posterior edge completely serrated; operculum with two weak spines, edge smooth; suboperculum and interoperculum with a few weak serrations; inside of gill chamber blackish; peritoneum black, anus immediately in front of origin of anal fin; principal caudal rays 17; pseudobranchiae large; gill membranes extending far forward, free from isthmus except where they join it at its anterior tip; branchiostegals 6 ; caudal forked.

Measurements.-The measurements outside the parentheses are in millimeters, and those in parentheses are expressed in hundredths of the standard length. Distance from tip of snout to base of midcaudal fin rays 105; greatest depth of body 30.5 (29) at origin of spiny dorsal; least depth of caudal peduncle 11.9 (11.3) ; length from base of last anal ray to base of midcaudal fin rays $25(23.8)$; head 37 (35.2) ; diameter of eye 10.8 (10.3); snout 9.0 (8.6); interorbital space $9.3(8.9)$; length of longest pectoral fin ray $26(24.8)$; length of second anal spine $9.6(9.1)$; length of longest dorsal fin spine or third spine 17 (16.2) ; tip of snout to origin of spiny dorsal fin 38.7 (36.8); tip of snout to origin of anal fin $71.3(68)$; tip of snout to insertion of pectoral fins 37 (35.2); tip of snout to insertion of pelvic fins 39.7 $(37.8)$; tip of snout to center of anus 67.8 (64.5) ; length of maxillaries 16.6 (15.8); color in alcohol, silvery on sides and belly, darker above.

This species is distinguished from other species in the genus Synagrops as indicated in the key.

\section{SYNAGROPS PHILIPPINENSIS (Günther)}

Acropoma philippinense* GüNTHER, Zoology of the voyage of H. M. S. Challenger, vol. 1 , pt. 6 , p. 51,1880 .

Parascombrops pellucidus Alcock, Journ. Asiat. Soc. Bengal, vol. 58, pt. 2, p. 296, pl. 22, fig. 1, 1889.

Synagrops malayanus WEBER, Die Fische der Siboga-Expedition, p. 196, fig. 52, 1913.

SYNAGROPS ARGYREA (Gilbert and Cramer)

Melanostoma argyreum* Gilbert and Cramer, Proc. U. S. Nat. Mus., vol. 19, p. 416 , pl. 39, fig. 3, 1897 . (U.S.N.M. No. 47732, holotype.)

SYNAGROPS GROSSIDENS (Smith and Radeliffe)

Amia (Amioides) grossidens* Sмmн and RAdcLmfe, in Radeliffe, Proc. U. S. Nat. Mus., vol. 41, p. 440, pl. 36, fig. 1, 1912 . (U.S.N.M. No. 70250, type.)

SYNAGROPS MICROLEPIS Norman

Synagrops microlepis* NoRMan, Discovery Reports, vol. 12, Coast fishes, pt. 1: The South Atlantic, p. 12, fig. 3, 1935. (U.S.N.M. No. 108186, paratype.) 
Holotype.-A male, $110 \mathrm{~mm}$. in standard length, taken by the First Johnson-Smithsonian Deep-sea Expedition, March 4, 1933, and bearing tin tag number 599, station 100, latitude $18^{\circ} 38^{\prime} 45^{\prime \prime} \mathrm{N}$., longitude $64^{\circ} 52^{\prime} 45^{\prime \prime} \mathrm{W}$., to latitude $18^{\circ} 40^{\prime} 15^{\prime \prime} \mathrm{N}$., longitude $64^{\circ} 50^{\prime} 15^{\prime \prime} \mathrm{W}$., which is off the Virgin Islands. U.S.N.M. No. 107203.

Description.-Body compressed, elongate, with large cycloid scales, most of which have been lost; lateral line continuous but not extending on caudal fin rays; interorbital space nearly flat; head with numerous spongy cavities; premaxillaries protractile; lower jaw longer than upper, slightly projecting; upper edge of maxillaries fitting into a groove formed by the suborbital and preorbital bones, and anteriorly the maxillaries are covered by the preorbitals; wide band of villiform teeth on the premaxillaries, the very outer ones a little enlarged at each side of the symphysis of premaxillaries is a large canine tooth, on right side a smaller tooth at base of large one, between this pair of large canines fits the symphyseal knob and a smaller pair of canines on lower jaw; lower jaw with a narrow band of sharp villiform teeth anteriorly, but at sides of jaw gradually becoming enlarged canines in one row numbering 8 or 9 , those in midside of jaw longest, and far apart; the region of the lower jaw at each side of the symphyseal canines is concave as in the genus Synagrops; teeth on vomer villiform in V-shaped patch, ending posteriorly in a few slightly enlarged teeth; palatine teeth small, conical in one or two irregular rows. Pelvics I, 5; dorsal rays IX, I, 10, a deep emargination in front of last spine and over ninth spine; first dorsal spine short, second about $21 / 2$ times length of first, third spine longest; front edge of no spine in any fin serrated; preoperculum with double edge, the lower angle of the anterior edge with 5 or 6 short spines the posterior edge at lower angle serrated as is lower edge; at lower angle of preoperculum, outer surface of posterior plate without the small keels; operculum with two weak spines; suboperculum at lower corner with edge bearing a few serrae; interoperculum also with some serrae; inside of gill chamber blackish; peritoneum jet black; anus just in front of origin of anal fin; principal caudal rays 17 ; pseudobranchiae present and large; gill membranes extending far forward free from isthmus; branchiostegals 7 ; first anal spine short, curved posteriorly, second anal spine long, broad, grooved behind.

Counts.-Dorsal rays IX, I, 10 ; anal rays II, 9 ; pectoral right 16 , leît 13 ? ; gill rakers $7+1+17$; scale formula about $3+35+$ ?.

Measurements.-The measurements outside parentheses are in millimeters, and those in parentheses are expressed in hundredths of standard length. Distance from tip of snout to base of midcaudal fin rays 110 ; greatest depth of body 33 (30.0) near origin of spinous 
dorsal fin; least depth of caudal peduncle 11.5 (10.5); length from base of last anal ray to base of midcaudal fin rays $18.8(17.1)$; head 43 (39.1) ; diameter of eye 15 (13.6) snout 7.3 (6.64); interorbital space $10.5(9.55)$; length of longest pectoral fin ray $33(30.0)$; length of second anal spine $10.5(9.55)$; tip of snout to origin of spiny dorsal fin 45.6 (41.5); tip of snout to origin of anal fin 75.6 (68.7); tip of snout to insertion of pectoral fins 42.6 (38.7); tip of snout to insertion of pelvic fin 44 (40.0); tip of snout to anus 70.6 (64.2); least width of bony suborbital 2.3 (2.18); length of maxillaries 21.3 (19.4).

Color in alcohol darker above; sides and belly silvery.

This species is distinguished from other species in the genus Synagrops as indicated in the key.

\section{SYNAGROPS BELLA (Goode and Bean)}

Hypoclydonia bella* GooDe and BEAN, Oceanic ichthyology, p. 236, pl. 66, fig. 237, 1895. (U.S.N.M. No. 39338, type ; Nos. 39346, 44621, 74325-74328, paratypes.)

TABLE 1.-Counts made on specimens of Synagrops in the U. S. National Museum

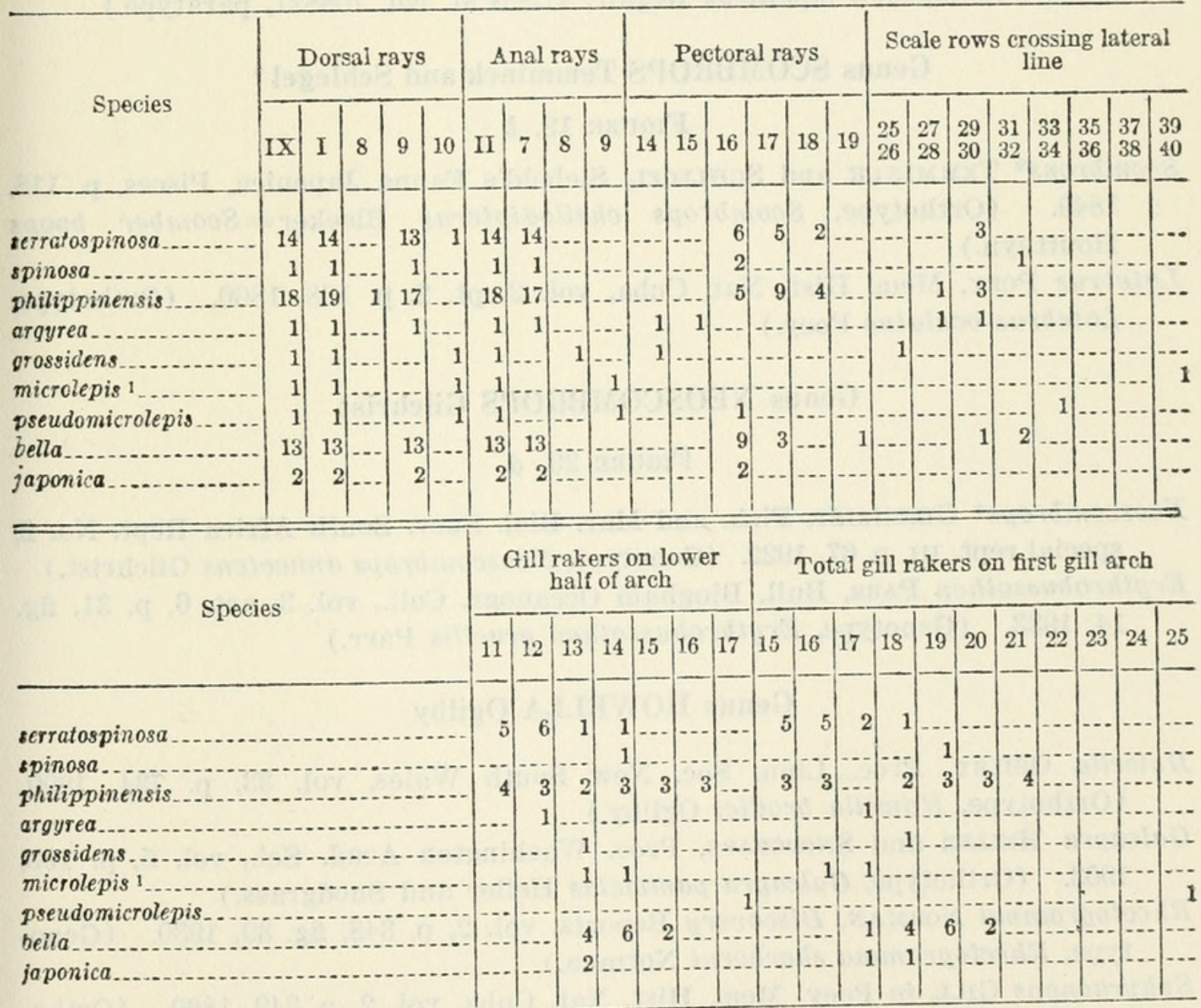

1 Data for one of these specimens of S. microlepis were taken from Norman, Discovery Reports, vol. $12,1935$. 


\section{SYNAGROPS JAPONICA (Steindachner and Döderlein)}

Melanostoma japonicum* DöDERLEIN, in Steindachner and Döderlein, Denkschr. Akad. Wiss. Wien. math.-nat. Classe, vol. 48, p. 5, pl. 1, fig. 2, 1883.

Synagrops natalensis Grchrist, Fish. and Mar. Biol. Surv. South Africa, Rept. No. 2, special rept. III, p. 69, 1922.

\section{Genus TELESCOPIAS Jordan and Snyder ${ }^{\circ}$}

Figure 19, $c$

Telescopias * Jordan and Snyder, Proc. U. S. Nat. Mus., vol. 23, p. 909, pl. 44, 1901. (Orthotype, Telescopias gilberti Jordan and Snyder: U.S.N.M. No. 57540 , paratype.)

\section{Genus PSEUDAMIA Bleeker}

Pseudamia Blekeker, Nederl. Tijdschr. Dierk., vol. 2, p. 284, 1865. (Type, Apogon polystigma Bleeker.)

\section{Genus GYMNAPOGON Regan ${ }^{\circ}$}

Figure $20, e$

Gymnapogon* Regan, Ann. Mag. Nat. Hist., ser. 7, vol. 15, p. 19, 1905. (Orthotype, Gymnapogon japonicus Regan; U.S.N.M. No. 108821, paratype.)

\section{Genus SCOMBROPS Temminck and Schlegel ${ }^{\circ}$}

Figure $19, b$

Scombrops* Temminck and Schlegel, Siebold's Fauna Japonica, Pisces, p. 118, 1849. (Orthotype, Scombrops cheilodipterus Bleeker=Scomber boops Houttuyn.)

Latebrus PoEY, Mem. Hist. Nat. Cuba, vol. 2, pt. 2, p. 168, 1860. (Orthotype, Latebrus oculatus Poey.)

\section{Genus NEOSCOMBROPS Gilchrist}

Figure 20, $d$

Neoscombrops* Gilchrist, Fish. and Mar. Biol. Surv. South Africa Rept. No. 2, special rept. III, p. 67, 1922. (Genotype, Neoscombrops annectens Gilchrist.)

Erythrobussothen PARR, Bull. Bingham Oceanogr. Coll., vol. 3, art. 6, p. 31, fig. 14, 1933. (Genotype, Erythrobussothen gracilis Parr.)

\section{Genus HOWELLA Ogilby}

Howella Oginbr, Proc. Linn. Soc. New South Wales, vol. 33, p. 734, 1899. (Orthotype, Howella brodiei Ogilby.)

Galeagra Hemler and Snodgrass, Proc. Washington Acad. Sci., vol. 5, p. 193, 1903. (Orthotype, Galeagra pammelas Heller and Snodgrass.)

Rhectogramma Norman, Discovery Reports, vol. 2, p. 348, fig. 39, 1930. (Genotype, Rhectogramma sherborni Norman.)

Sphyraenops GiLL, in Poey, Mem. Hist. Nat. Cuba, vol. 2, p. 349, 1860. (Orthotype, Sphyraenops bairdianus Poey.)

'The placing of Scombrops, Telescopias, and Gymnapogon in the family Pomatomidae by Regan (Ann. Mag. Nat. Hist., ser. 8, vol. 12, pp. 117-118, 1913) does not seem justified to me at this time. Further study is necessary to establish relationships. 


\section{Genus BATHYSPHYRAENOPS Parr}

Bathysphyraenops PARR, Bull. Bingham Oceanogr. Coll., vol. 3, art. 6, p. 28, fig. 13, 1933. (Genotype, Bathysphyraenops simplex Parr.)

\section{Genus APOGONOPS Ogilby}

Figure $19, g$

Apogonops OgILby, Proc. Linn. Soc. New South Wales, vol. 21, p. 23, 1896. (Orthotype, Apogonops anomalus Ogilby.)

Parasphyraenops T. H. Besn, Proc. Biol. Soc. Washington, vol. 25, p. 124, 1912.

(Orthotype, Parasphyraenops atrimanus* Bean: U.S.N.M. No. 74085, type.)

\section{Genus BREPHOSTOMA Alcock}

Brephostoma Alcock, Ann. Mag. Nat. Hist., ser. 6, vol. 4, p. 383, 1889. (Orthotype, Brephostoma carpenteri Alcock.)

\section{Genus BRINKMANNELLA Parr}

Brinkmannella PARr, Bull. Bingham Oceanogr. Coll., vol. 3, art. 6, p. 26, fig. 12, 1933. (Genotype, Brinkmannella elongata Parr.) 


\section{$2 \mathrm{BHL}$ Biodiversity Heritage Library}

Schultz, Leonard P. 1940. "Two new genera and three new species of cheilodipterid fishes, with notes on the other genera of the family." Proceedings of the United States National Museum 88(3085), 403-423. https://doi.org/10.5479/si.00963801.88-3085.403.

View This Item Online: https://www.biodiversitylibrary.org/item/32771

DOI: https://doi.org/10.5479/si.00963801.88-3085.403

Permalink: https://www.biodiversitylibrary.org/partpdf/33553

\section{Holding Institution}

Smithsonian Libraries

\section{Sponsored by}

Smithsonian

\section{Copyright \& Reuse}

Copyright Status: NOT_IN_COPYRIGHT

Rights: https://www.biodiversitylibrary.org/permissions/

This document was created from content at the Biodiversity Heritage Library, the world's largest open access digital library for biodiversity literature and archives. Visit BHL at https://www.biodiversitylibrary.org. 